\title{
The Effect of Funding Decisions and Intellectual Capital on Firm Value with Profitability as an Intervening Variable in Manufacturing Companies Listed on the Indonesia Sharia Stock Index
}

\author{
Fitra Nur Uswatun Khasanah, D. Agus Harjito
}

\begin{abstract}
This study examines the effect of funding decisions and intellectual capital on firm value with profitability as an intervening variable in manufacturing companies listed on the Indonesia Sharia Stock Index (ISSI). This study uses DER as an indicator of funding decisions, VAIC as an indicator of intellectual capital, ROA as an indicator of profitability and Tobin's $Q$ as an indicator of corporate value. The sample used in this study is the manufacturimg companies listed on the Indonesia Sharia Stock Index (ISSI) in the 2014-2018 period. The data obtained were 290 samples. This study uses multiple regression to analyze data and path analysis to determine the effect of mediation. The results showed that funding decisions have a negative effect on profitability, intellectual capital has a positive effect on profitability. Funding decisions (DER) and profitability (ROA) have a positive effect on firm value (Tobin's $Q$ ) but intellectual capital (VAIC) has a negative effect on firm value (Tobin's Q). Profitability (ROA) can't mediate the effect of funding decisions (DER) on firm value (Tobin's Q) but profitability (ROA) can mediate the effect of intellectual capital (VAIC) on firm value (Tobin's Q).
\end{abstract}

Index Terms-Funding Decisions, Intellectual Capital, Profitability, Firm Value.

\section{INTRODUCTION}

The fourth industrial revolution or industry 4.0 revolution encourage companies to have global competitiveness including companies in Indonesia. Different from the previous industri era, the industry 4.0 is based on intelligent production, which means that the industry is more knowledgeable. It is an investment opportunity for the companies. Investment requires capital to obtain future income. In this study divides capital into two types namely material capital and non-material capital. The material capital is physical funding from internal and external companies. While non-material capital is intangible capital

Fitra Nur Uswatun Khasanah, Master of Management Program, Indonesia Islamic University, Yogyakarta, Indonesia

Dwipraptono Agus Harjito, Department of Management, Indonesia Islamic University, Yogyakarta, Indonesia such as knowledge, expertise, skills, reputation etc.

The funding decision for companies are the most important thing to supporting the company's activities. This is combination of internal (debt) and external (equity) funding. Generally referred to as a capital structure. If the companies uses a lot of debt and can manage it well so that it will have an impact on increased probability. The result of previous studies supporting this statement were carried out by Ahmad et.at (2015), Chesang \& Ayuma (2016), Mahardhika \& Marbun (2016), Dalci (2018) that the use of debt can increase probability. But the different result were found by Widiyanti \& Elfina (2015), Laksono \& Pangestuti (2018).

The use of debt can affect on the firm value but depending on the perception of on stakeholders such as investor and creditor. For creditors, debt is a trust for the company because they considers the company can repay the debt and has a positive cash flow. For investors, debt is an opportunity for companies to develop their businesses. So that the company is expected to provide more profit for investors. Sari (2017) and Tauke et.al (2017) found that the capital structure had positive effect on the firm value. But Rahmantio et.al (2018), Maulana et.al (2016), Tanudja \& Hastuti (2019) found that debt to equity ratio (DER) had no significant effect on the firm value.

The company's financial statements are an overview of the management's performance in managing the debt. If the company can manage the debt well then it effects the increase in profits. It the company has a high profit, it means the company's profitability is good so the firm value will increase. Hamidy et.al (2015) found the result that profitability can mediate the effect of DER as an indicator of capital structure on the firm value. While Pratama \& Wiksuana (2018) found that profitability can't mediate of the effect of leverage on the firm value.

Companies must also have non-material capital in the form of intangible assets that are often referred to as intellectual capital. Where the intellectual capital has a high potential in creating value added for the company. Value added is the most objective indicator in assessing business success and demonstrating the company's ability to value creation (Ulum, 2017).

The intellectual capital phenomenon in Indonesia emerged since the issuance of the revised PSAK no 19 year 2010 about intangible assets. Although intellectual capital is indirectly mentioned in accounting standards, but the discussion about it has gained attention in accounting. However, in the reality companies in Indonesia have not fully focused on intellectual capital. Indonesia's industry still uses 
conventional based and still uses traditional accounting that emphasizes the use of tangible assets. So that the traditional financial statements can't present information on intangible asset overall.

Productivity can be increased due to the good management of intellectual capital. So that it will impact the increasing profitability. Chowdhury et.al (2018), Chen et.al (2005), Barokah et.al (2018), Kazhimy \& Sulasmiyati (2019), Kuspinta \& Husaini (2018), Hermawan et.al (2019) found that intellectual capital has a positive effect on the profitability. But Putri \& Nuzula (2019) found the opposite result.

The company that owns the good intellectual capital is a positive signal for outsiders in assessing the company. That means the company is considered able to compete and has a competitive advantage so it is expected to win industry competition. Putri \& Nuzula (2019) found that intellectual capital increased then the firm value will also increase. But Nimtrakoon (2015) showed the different result that the intellectual capital has no positive effect on firm value.

If the management of intellectual capital is good and right then it can impact on the profitability positively. It will be seen from the income statement of the company. If the company profitable then the investor will respon it as a positive signal from management, that it can increase the firm value. Therefore, the company's profitability as an evidence in financial reporting can mediate the effect intellectual capital on firm value. Sudibya \& Restuti (2014) found that the financial performance as an intervening variable can mediate the relationship between intellectual capital and corporate value. Meanwhile, Fazrin \& Hermanto (2019) found the result that the profitability can't mediate the relationship between intellectual capital and stock return.

Profitability is one of the factors that can give an impact on firm value. Because profitability is the ability of the company to generate profits. Tauke et.al (2017), Haryanto et.al (2016) found that profitability has a positive significant on the firm value. But Pratama \& Wiksuana (2018) found the different result.

The novelty in this study is by the intervening variable of profitability that can give a more effective effect between variable independent on variable dependent. In addition, the reason for using ratio DER as indicator of funding decision is that ratio can measure the company's health and it can find out about how much the company's debt affects on the management of assets (Permatasari \& Azizah, 2018). Intellectual capital is measured using the VAIC method. Because the data is more easily to obtained from financial statements. Profitability is measured using Return on Assets (ROA) because it measures the company's ability to generate net profit by using total assets after interest and taxed. While the firm value is measured using the ratio Tobin's Q because this ratio describes a condition of investment opportunity owned by the company (Lang, et.al. 1989) or the company's growth potential (Tobin, 1969) and the reflects market sentiment.

The object of this study is the sector manufacture companies listed on the Indonesia Shariah Stock Index (ISSI) because that sector is still the main support in economic growth in Indonesia (detikfinance.com). While the growth of investor in Sharia stock market today increases dramatically, which increases more than 100 times in a span of seven years
(Kontan.co.id). This research is important to do because of some previous studies there are still research gaps and inconsistencies in the result. Moreover, there is still a need for proof between theory and existing reality that is related to these variables. The existence of industrial development in the era of the revolution industrial 4.0 became an urgency in this research.

\section{LITERATURE REVIEW AND DEVELOPMENT OF HYPOTHESIS}

\section{A. Firm Value}

Firm value is a factor that influences a company's investment decisions. Investor will see the value of the company before making an investment. If the companies that have high company value, it can be said that the company has good prospect for the growth in the future, so it is attractive for investors to investment (Permatasari \& Azizah, 2018). The high company value indicates the high prosperity of shareholders, because of the maximum stock price. The present value of the all expected profits in the future can be reflected on the value of company (Horne, 2009).

\section{B. Profitability}

Profitability is a reflection of company performance and it is an image of the company's management performance. The high company's profitability illustrates that the company's performance is good. This profitability is an information on the company's financial performance needed by investors in investing. The investors decision will be reflected in the company's stock price and it is affected by the company's ability to generate profits (Haryanto et.al, 2016).

\section{Funding Decision}

Funding decisions are related to how the companies manage the source of funds used. This it is related to the type of source of funds, the amount of funds, the composition, the cost of funding resources (Prihadi, 2013). The capital structure is part of the company's funding decisions, where the capital structure is a balancing between the short-term debt, long-term debt, preferent stock and ordinary stock (Sartono, 2010). The optimal capital structure can be interpreted as minizing the use of the overall capital costs or average capital cost (Harjito \& Martono, 2007).

\section{Intellectual Capital}

Intellectual capital is intangible capital from the performance of capital employee, human capital and structural capital (Pulic, 1998). As for knowing how well an intellectual capital performance in a company, Mavridis (2004), Kamath (2007) and Ulum (2008) used the business performance indicator (BPI). Where the BPI is an indicator to measure the performance of intellectual capital based on VAIC scores classified in 4 categories. In this study used 4 categories which is using by Ulum (2008): 
1) Top Performers - VAIC score more than 3 point

2) Good Performers - VAIC score between 2.0 until 2.99 point

3) Common Performers- VAIC score between 1.5 until 1.99 point

4) Bad Performers- VAIC score less than 1.5 point

\section{E. Hypothesis Development}

1) The effect funding decision on profitability

Dalci (2018) reveals that in the theory of capital structure, laverage affects profitability because of taxes, agency costs, financial distress, bankruptcy costs and asymmetry information as disclosed by Modigliani \& Miller (1963); Scott (1977); Jensen \& Meckling (1976); Myers \& Majluf (1984); Myers (2001).

Ali (2017) found a positive relationship between the capital structure (Debt ratio) and financial performance (ROA) (Sudaryo \& Pratiwi, 2016; Permatasari et.al, 2018) but did not find a positive relationship to return on equity (ROE). Ahmad et.al (2015), Chesang \& Ayuma (2016), Mahardhika \& Marbun (2016) found that DER has an effect on profitability. Dalci (2018) found that there was a positive effect over the financial leverage on profitability. Therefore, based on the explanation, the hypothesis in this study was:

$H_{1}=$ Funding decisions have a positive effect on profitability.

2) The effect intellectual capital on profitability

Based on the theory of stakeholders, the creation of value in the company the company is to maximaze the potential owned such as employees (human capital), physical assets (physical capital) or structural capital. If this potential is managed properly, it will be able to create a value added for the company and then it can increase the financial performance for the benefit of the stakeholder (Ulum, 2017). Chowdhury et.al (2018) showed the impact of VAIC component on financial performance. Kuspinta \& Husaini (2018), Sardo et.al (2018), Barokah et.al (2018), Kazhimy \& Sulasmiyati (2019) showed that intellectual capital efficiency has a positive impact on financial performance. Therefore, based on the explanation, the proposed hypothesis in this study was:

$H_{2}=$ Intellectual capital has a positive effect on profitability.

3) The effect profitability on firm value

The high profitability indicates that the company can make efficiency in the asset turnover, so investors will tend to respond positively to the company. Which the response will have an impact on the firm value. Signalling theory explained that if the information from the company was responded positively by the market then the firm value will increase, but if it turn out that the response is negative, the firm value will decrease (Haryanto et.al, 2016). Nuryaman (2015), Haryanto et.al (2016), Sabrin (2016) found that profitability affected firm value. Therefore, based on the explanation, the proposed hypothesis in this study was:

$H_{3}$ = Profitability has a positive effect on firm value.

4) The effect funding decision on firm value

The Trade Off theory can be predicted a positive effect between the use of debt and the increase of firm value. Ross (1977) expanded the analysis and proposed that the high debt ratio of the company gave a positive signal to the market that the company has a positive cash flow to fulfill the company's operational and financing requirements in the future. Jensen \& Meckling (1976) also suggested that debt or leverage affects the company's performance. The high debt ratios reduce to the company's agency costs due to the liquidation threat and risk reduction of company managers rewards.

Tauke et.al (2017), Sari (2017), Pratama \& Wiksuana (2018) found the capital structure has a positive and significant effect on the value of the firm. The higher the debt, the higher the firm value. Therefore, based on the explanation, the hypothesis in this study was:

$H_{4}=$ Funding decisions have a positive effect on the firm value.

5) The effect intellectual capital on firm value

According to the Resourced Based View Theory, company-owned resources can make the company to have a competitive advantage and to have a good performance in the long term (Ulum, 2017). The good intellectual capital will be able to create efficiency, so that it will raise the performance of the company that will increase eventually the value of the firm (Hafidhah \& Herli, 2017).

Based on the signalling theory, Petty \& Guthrie (2000) and Whiting \& Miller (2008) argued that a voluntary disclosure of information about ownership of intellectual capital is an effective means of communication for the company to convey a quality signal to create prosperity in the future.

Mariani \& Suryani (2018), Smriti \& Niladri (2018), Putri \& Nuzula (2019), Nuryaman (2015) found that intellectual capital has an effect on the firm value. Therefore, based on the explanation, the hypothesis in this study was:

$H_{5}=$ Intellectual capital has a positive effect on firm value.

6) The effect funding decisions on firm value through profitability

The efficient debt management and not more than the optimal point will impact to increase profitability. If the company has the good profitability then it will increase the firm value because the demand for shares rises (Nurhayati, 2013). So it can be said that the use of debt by the company indirectly affects the firm value.

Hamidy et.al (2015) found the result that profitability can mediate the relationship between DER as an indicator of capital structure on the firm value. Dewi \& Abundati (2019) found that profitability significantly mediated the effect leverage on firm value. Therefore, based on the explanation, the hypothesis in this study was:

$H_{6}=$ Profitability mediate the effect of relationship between funding decisions on firm value.

7) The effect intellectual capital on firm value through profitability

The good intellectual capital management can increase the value added. The value added is very useful gaining a competitive advantage. The value creation of intellectual capital is maximizing human capital, physical capital and structural capital. According to the stakeholder theory, the company not only operates for its own benefit, but also for the benefit of stakeholders. These stakeholders include as employees, communities, investor etc. If the resources managed well, it will increase profitability. The investors will that information as a positive information. Then it will be responded positively so the firm value increases and it will be able to improve the welfare of shareholders. 
The Effect of Funding Decisions and Intellectual Capital on Firm Value with Profitability as an Intervening Variable in Manufacturing Companies Listed on the Indonesia Sharia Stock Index

Sudibya \& Restuti (2014), Muna \& Prastiwi (2014), Yuskar \& Novita (2014), Nuryaman (2015), Simanungkalit (2015) and Jayanti (2017) found the result that the financial performance can mediate the relationship between capital structure on firm value. Therefore, based on the explanation, the hypothesis in this study was:

$H_{7}=$ Intellectual capital mediate the effect of relationship between funding decisions on firm value.

\section{RESEARCH METHODS}

This research is a quantitative study using the pool data that are combined from time series and crosssection data. The population of this research is the manufacturing company listed on the Indonesia Sharia Stock Index (ISSI) period 2014-2018 and the semple obtained by 58 companies with the purposive sampling method.

The data source from annual report and financial report taken from www.idx.co.id or on the official website of each company.

The variables in this study is Firm Value (Y), Profitability (M), Funding Decisions (X1), Intellectual Capital (X2) and the indicators from each that variables used:

A. Dependent Variable : Firm Value

$$
\text { Tobin's } Q=\frac{M V E+D e b t}{T A}
$$

Description:

MVE $=$ Market value of all outstanding shares

Debt $=$ Total Debt

TA $=$ Total Activa

B. Intervening Variable: Profitability

$$
\text { ROA }=\frac{\text { EAT }}{\text { Total Asset }}
$$

Description:

EAT $=$ Earning After Tax

C. Independent Variables

1) Funding Decisions

$$
\text { DER }=\frac{\text { Total Debt }}{\text { Equity }}
$$

2) Intellectual Capital

$$
\begin{aligned}
& \text { Estimate Value Added } \\
& \text { VA }=\text { OUT }-I N
\end{aligned}
$$

Description:

VA $=$ Value Added (Difference between output and input)

OUT $=$ Total Sales and other income

IN = Expenses and the other costs (except employee cost)

b) Estimate VACA (Value Added Capital Employee)

$$
V A C A=\frac{V A}{C E}
$$

Description:

$\mathrm{VACA}=$ Ratio from VA to CE

$\mathrm{VA}=$ Value Added

$\mathrm{CE}=$ Available funds (equity, net profit)

c) Estimate VAHU (Value Added Human Capital)

$$
V A H U=\frac{V A}{H C}
$$

Description:

$\mathrm{VAHU}=$ Ratio from VA to HC

$\mathrm{VA}=$ Value added

$\mathrm{HC}=$ labor expense or employee cost (total salary, wages and employee income)

d) Estimate STVA (Structural Capital Value Added)

Description:

$$
S T V A=\frac{S C}{V A}
$$

STVA = Ratio from SC to VA

$\mathrm{VA}=$ Value added

$\mathrm{SC}=\mathrm{VA}-\mathrm{SC}$

$$
\begin{aligned}
& \text { Estimate VAIC (Value Added Intellectual } \\
& \text { Capital) } \\
& \text { VAIC }=\text { VACA }+ \text { VAHU }+ \text { STVA }
\end{aligned}
$$

Testing the hypothesis in this study uses multiple regression estimation while to measure mediation effect using path analysis. Statitical test analysis uses Eviews 10 software. Data analysis techniques use descriptive statistical test, classical assumsions (multikolinearitas test, heteroskedastisitas test), hypothesis testing and path analysis. This study used two regression equation are:

$$
R O A=\alpha_{1}+\beta_{1} D E R+\beta_{2} V A I C+\varepsilon
$$$$
\text { TOBIN } S Q=\alpha_{2}+\beta_{3} D E R+\beta_{4} V A I C+\beta_{5} R O A+\varepsilon
$$

\section{RESULT AND DISCUSSION}

\section{A. Descriptive Statistic Analysis}

Table 1. Descriptive Statistic Analysis

\begin{tabular}{|l|c|c|c|c|}
\hline & DER & VAIC & ROA & TQ \\
\hline Mean & 0.7178 & 3.1546 & 0.0589 & 1.9465 \\
\hline Median & 0.5619 & 2.7713 & 0.0514 & 1.0127 \\
\hline Maximum & 3.1287 & 13.585 & 0.4666 & 23.2857 \\
\hline Minimum & 0.0010 & -4.7108 & -0.4646 & 0.2114 \\
\hline Std. Dev. & 0.5450 & 1.7565 & 0.0852 & 2.8463 \\
\hline Observations & 290 & 290 & 290 & 290 \\
\hline
\end{tabular}

Source: Output Eviews 10, 2020

Mean score of DER as of 0.7178 , maximum score as of 3.1287 owned by PT SAT Nusapersada Tbk in 2018. Minimum score as of 0.0010 owned by PT Nippon Indosari Corporindo in 2016. Mean score of VAIC as of 3.1546, maximum score as of 2.7713 owned by 13.5854 in 2014 owned by PT Astra International Tbk and minimum score as of -4.7108 owned by PT Keramika Indonesia Assosiasi Tbk in 2018 because this company suffered a loss. Mean score of ROA as of 0.0589 , maximum score as of 0.4666 owned by PT Unilever Tbk in 2018 and minimum score as of -0.4646 owned by PT Keramika Indonesia Assosiasi Tbk in 2018. Mean score of TQ as of 1.9465, maximum score as of 23.2857 owned by PT Unilever Tbk in 2017 and minimum score as of 0.2114 owned by PT Merck Tbk in 2018.

\section{B. Classic Assumsion Test}

Testing the classic assumsion on the data has been freed from the symptoms of multicolinearity but there are symptoms of heteroskedastisity which is then resolved using the robust standart error test. 


\section{Regression Result}

The best regression models of the regression model selection is Random Effect Model for model 1 and Fixed Effect Model for model 2.

Table 2. Random Effect Model for Model 1

\begin{tabular}{|c|c|c|c|c|}
\hline \multicolumn{5}{|c|}{ Dependent Variable: ROA } \\
\hline Variable & Coefficient & $\begin{array}{r}\text { Std. } \\
\text { Error }\end{array}$ & t-Statistic & Prob. \\
\hline $\mathrm{C}$ & -0.0178 & 0.0115 & -1.5543 & 0.1212 \\
\hline DER & -0.0259 & 0.0068 & -3.7736 & 0.0002 \\
\hline VAIC & 0.0302 & 0.0021 & 13.9584 & 0.0000 \\
\hline R-squared & & & & 0.4135 \\
\hline \begin{tabular}{|l|} 
Adjusted \\
R-squared
\end{tabular} & & & & 0.4094 \\
\hline Prob(F-statistic) & & & & 0.0000 \\
\hline
\end{tabular}

Source: Output Eviews 10, 2020

Table 3. Fixed Effect Model for Model 2

\begin{tabular}{|c|r|r|r|r|}
\hline \multicolumn{5}{|c|}{ Dependent Variable: TQ } \\
\hline Variable & Coefficient & $\begin{array}{r}\text { Std. } \\
\text { Error }\end{array}$ & t-Statistic & Prob. \\
\hline C & 1.8158 & 0.0731 & 24.8306 & 0.0000 \\
\hline DER & 0.2541 & 0.0370 & 6.8623 & 0.0000 \\
\hline VAIC & -0.0844 & 0.0296 & -2.8478 & 0.0048 \\
\hline ROA & 3.6402 & 0.5008 & 7.2682 & 0.0000 \\
\hline R-squared & & & 0.9426 \\
\hline Adjusted & & & \\
R-squared & \multicolumn{5}{|c}{0.9275} \\
\hline Prob(F-statistic) & \multicolumn{5}{|c}{0.0000} \\
\hline
\end{tabular}

Source: Output Eviews 10, 2020

Based on the regression result table above then the regression equation is formed by looking at the coefficient on each of the variable as follows:

$R O A=-0.0178-0.0259 D E R+0.0302 V A I C+\varepsilon$ $T Q=1.8158+0.2541 D E R-0.0844 V A I C+3.6402 R O A+\varepsilon$

\section{Hypothesis Testing}

\section{1) $T$ Test}

$\mathrm{T}$ test can be done by comparing between $\mathrm{T}$-statistic with T-table or it can be done by comparing probability value with alpha. Table 2 showed the probability at DER of $0.0002<$ alpha $5 \%$, VAIC of $0.0000<$ alpha $5 \%$ so it means that DER and VAIC affects on the ROA. Table 3 showed that the probability at DER of 0.0000 , VAIC of 0.0048 , ROA of 0.0000 . all of them are less than alpha $5 \%$, so it means that DER, VAIC, ROA affects on the TQ.

2) Coefficient of Determination

Table 2 showed that the Adj. R Square in the amount of $0.4094(40 \%)$, it mean is DER and VAIC had an affect on ROA of $40 \%$ and $60 \%$ was affect by other variable. Table 3 showed that the Adj. R Square in the amount of 0.9275 (92\%), it mean is DER, VAIC, ROA had an affect on TQ of $92 \%$ and $8 \%$ was affect by other variable.

\section{E. Path Analysis}

This analysis is done by comparing the coefficient of indirect effect with the direct effect coefficient. If the indirect coefficient is greater than the direct coefficient, the effect of independent variable on the dependent variable is mediated by the intervening variable, vice versa.
Figure 1. Path Analysis

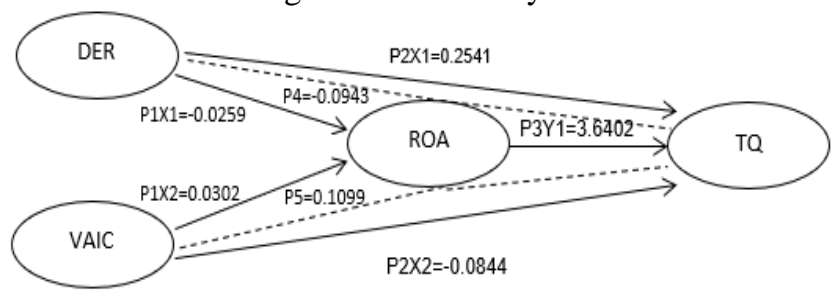

Model 1: the coefficient of Indirect effect $(-0.0259 * 3.6402=-0.0943)>$ the coefficient of direct effect (0.2541). Model 2: the coefficient of direct effect $(0.0302 * 3.6402=0.1099)>$ the coefficient of direct effect $(-0.0844)$.

\section{F. Discussion}

\section{1) The effect funding decision on profitability}

Based on the result that $H_{1}$ rejected. The funding decisions have not a positive effect on profitability. If the company chooses to add more debt, so that the cost of debt incurred also higher then the thing that happens will be able to decrease the profitability of the company. Because more debt will pose a bankruptcy threat to the company. This is evidenced by the increase in debt made by PT Indocement Tunggal Perkasa (INTP) in 2018, PT Multistrada Arah Sarana (MASA) in 2018 resulted in a profit decline.

The use of debt regulation in Sharia Stock have been determined with maximum of $45 \%$ (www.idx.co.id) so that the companies would prefer more use of its own equity than on debt. Previous research that supported the result was conducted by Prakoso \& Chabachib (2016), Ramadita \& Suzan (2019), Widiyanti \& Elfina (2015), Laksono \& Pangestuti (2018). While the opposite result was conducted by Ali (2017), Ahmad et.al (2015), Chesang \& Ayuma (2016), Mahardhika \& Marbun (2016), Dalci (2018), Sudaryo \& Pratiwi (2016), Permatasari et.al (2018).

2) The effect intellectual capital on profitability

Based on the result that $\mathrm{H}_{2}$ received. Intellectual capital has a positive effect on profitability. This result is evidenced by the fact of the company has been aware about the importance of value added for their company. As done by PT Astra International Tbk (ASII) and PT Unilever Tbk (UNVR) that have the performance of intellectual capital more than 3.00 point. According to Business Performance Indocator (BPI) means it Top Performers. So that makes the profitability increase.

Chen et.al (2005), Chowdhury et.al (2018), Barokah et.al (2018), Kazhimy \& Sulasmiyati (2019), Kuspinta \& Husaini (2018) and Sardo et.al (2018) showed the eficiency of intelletual capital on financial performance. While Juanda et.al (2016), Yulandari \& Gunawan (2019) and Putri \& Nuzula (2019) found the opposite result.

3) The effect profitability on firm value

Based on the result that $H_{3}$ received. The profitability has an effect on firm value. The company that profit is positive information. Because it is considered that the company has good prospects for the future. This will be responded by the market positively. The positive response can be demonstrated by increasing the stock price.

Hera \& Pinem (2017), Azmi et.al (2018), Haryanto et.al (2016) found that profitabiliity has a positive effect on the 
firm value. While Pratama \& Wiksuana (2018) found the opposite result.

\section{4) The effect funding decision on firm value}

Based on the result that $H_{4}$ received. The funding decisions has a positive effect on firm value. The increase in debt done by manufacturing companies is seen as positive information for investors so that the perception of investors to the company is good and can increase the firm value. As is the case done by PT Unilever Tbk (UNVR) in 2014-2017, BTON in 2015-2018, CTBN in 2016-2017, DVLA in 2016-2017, EKAD in 2016-2017, GDST in 2015-2017, INAF in 2016-2017, INDR in 2014-2015, KDSI in 2014-2018, KIAS in 2017-2018, LION in 2014-2015, RICY in 2016-2018, SIDO in 2017-2018, SKLT in 2017-2018, TRIS in 2015-2016, TRST in 2017-2018.

Hamidy et.al (2015), Sari (2017), Tauke et.al (2017) and Pratama \& Wiksuana (2018) found that capital structure has a positive effect on firm value. But Rahmantio et.al (2018), Maulana et.al (2016), Tanudja \& Hastuti (2019) found the opposite result.

\section{5) The effect intellectual capital on firm value}

Based on the result that $H_{5}$ rejected. Intellectual capital has no a positive effect on firm value. Because the intellectual capital management is bad, so the company can't create value added. Though it is very important in the industry 4.0. Not all the companies list the Intellectual capital performance disclosures in their annual report and not all of them make sustainability reporting on intellectual capital separately. So it would be difficulted for investors to assess how much the company's intellectual capital performance. Moreover, an intellectual capital measurement that can't still be clearly solved.

Nimtrakoon (2015), Lestari (2017), Utami (2019), Li \& Zhao (2017) found that intellectual capital has a negative effect on firm value. While Smriti \& Nilandri (2018), Putri \& Nuzula (2019) found the opposite result.

\section{6) The effect funding decisions on firm value through profitability}

Based on the result that $H_{6}$ rejected. Profitability can't mediate an effect between funding decisions on firm value. Because just by looking at the total debt and total equity, investors can already to provide a perception on company.

Pratama \& Wiksuana (2018), Hera \& Pinem (2017) found capital structure has no significant effect on the firm value through profitability. But Hamidy et.al (2015) found the opposite result.

\section{7) The effect intellectual capital on firm value through} profitability

Based on the result that $H_{7}$ received. Profitability can mediate an effect between funding decisions on firm value. The good intellectual capital management will have an impact on increasing company profitability. It means that the company profitable. Then the investors will give the positive response on that positive information. So that it can increase the firm value.

Muna \& Prastiwi (2014), Yuskar \& Novita (2014) found that profitability can mediate relationship between intellectual capital and firm value. But Sudibya \& Restuti (2014), found the opposite result.

\section{CONCLUTION}

Funding decisions have a negative effect on profitability if the debt exceeds the optimum limit and intellectual capital has a positive effect on profitability. Funding decisions and profitability have a direct effect on firm value, but intellectual capital haven't it. While profitability can't mediate an effect between funding decisions on firm value. But profitability can mediate an effect between intellectual capital on firm value.

\section{REFERENCES}

[1] Ahmad, N., Salman, A., \& Shamsi, A. F. (2015). Impact of Financial Leverage on Firm's Profitability: An Investigation From Cement Sector of Pakistan. Research Journal of Finance and Accounting. www.iiste.org. ISSN 2222-1697 (Paper) ISSN 222-2847 (Online). Vol. 6, Issue 7.

[2] Ali, A. (2017). The Relationship Between Capital Structure and Financial Performance in The Companies Listed in Abu Dhabi Securities Exchange: Evidence From United Arab Emirates. Review of European Studies. Vol. 9, Issue. 2; 2017. ISSN 1918-7173 E-ISSN 1918-7181. http://doi.org/10.5539/res.v9n2p1. Published by Canadian Center of Science and Education.

[3] Azmi, N., Isnurhadi \& Hamdan. 2018. Pengaruh Profitabilitas, Ukuran Perusahaan terhadap Nilai Perusahaan dengan Struktur Modal sebagai Variabel Intervening Pada Perusahaan Manufaktur yang Terdapat di BEI. Jurnal Ilmiah Manajemen Bisnis dan Terapan. 15(2), 95-108. Doi: http://doiorg/10.29259/jmbt.v15i2.6657.

[4] Barokah, S., Wilopo \& Nuralam, I. P. (2018). Pengaruh Intellectual Capital terhadap Financial Performance (Studi Pada Perusahaan Sub Sektor Property dan Real Estate Yang Terdaftar di Bursa Efek Indonesia (BEI) Tahun 2014-2016. Jurnal Administrasi Bisnis (JAB). $\begin{array}{llllll}\text { Vol. } & 55 & \text { Issue } & 1 & \text { Februari } & 2018\end{array}$ Administrasibisnis.studientjournal.ub.ac.id.

[5] Chen, M., Cheng, S., \& Hwang, Y. (2005). An Empirical Investigation of The Relationship Between Intellectual Capital and Firm's Market Value and Financial Performance. Journal of Intellectual Capital. Vol. 6 No. 2, 2005 pp. 159-176 q. Emerald Group Publishing Limited 1469-1930 DOI 10.1108/14691930510592771.

[6] Chesang, D., \& Ayuma, C.O. (2016). Effect of Financial Leverage On Profitability of Listed Agricultural Firms at The Nairobi Secirities Exchange. International Journal of Economics, Commerce and Management. United Kingdom. Vol. IV, Issue 12, December 2016. http://ijecm.co.uk/. ISSN 23480386.

[7] Chowdhury, L.A.M., Rana T., Akter, M \& Hoque, M. (2018). Impact of Intellectual capital on financial performance: Evidence from the Bangladeshi Textile Sector. Journal of Accounting \& Organizational Change. Vol. 14 Issue 4, pp. 429-454. DOI: 10.1108/JAOC-11-2017-0109.

[8] Dalci, I. (2018). Impact of Financial Leverage on Profitability of Listed Manufacturing Firm in China. Pasific Accounting Review. (C) Emerald Publishing Limited. 0114-0582. DOI 10.1108/PAR-01-2018-0008

[9] Dewi, N. P. I. K., \& Abundanti, N. (2019). Pengaruh Leverage dan Ukuran Perusahaan terhadap Nilai Perusahaan dengan Profitabilitas sebagai Variabel Mediasi. E-Jurnal Manajemen. Vol. 8 Issue 5. 3028-3056ISSN : 2302-8912 DOI: https://doi.org/10.24843/EJMUNUD.2019.v08.i05.p16.

[10] Fazrin, R., \& Hermanto. (2019). Pengaruh Intellectual Capital terhadap Return Saham dengan Profitabilitas sebagai Variabel Intervening. E-JA e-Jurnal Akuntansi. E-ISSN 2302-8556. Vol. 29 Issue 1 Hal 145-157.

[11] Hafidhah \& Herli, M. (2017). Pengaruh Modal Intelektual terhadap Nilai Perusahaan dengan Profitabilitas sebagai Variabel Moderasi. Jurnal "PERFORMANCE" Bisnis \& Akuntansi. Volume 7 Issue 2 September 2017.

[12] Hamidy, R. R., Wiksuana, I.G.B., \& Artini, L.G.S. (2015). Pengaruh Struktur Modal terhadap Nilai Perusahaan dengan Profitabilitas sebagai Variabel Intervening Pada Perusahaan Properti dan Real Estate di Bursa Efek Indonesia. E-Jurnal Ekonomi dan Bisnis Universitas Udayana 4.10 (2015) : 665-682. ISSN : 2337-3067.

[13] Harjito, D.A \& Martono. (2007). Manajemen Keuangan. Edition 2. Yogyakarta: EKONOSIA.

[14] Haryanto, S., Rahardian, N., Mbapa, M.F.I., Rahayu, E. N., \& Febriyanti, K. V. (2016). Kebijakan Hutang, Ukuran Perusahaan dan 
Kinerja Keuangan terhadap Nilai Perusahaan: Industri Perbankan di Indonesia. AFRE Accounting and Financial Review. 1(2): 62-70, 2018 http://jurnal.unmer.ac.id/index.php/afre.

[15] Hera, M. D. E., \& Pinem, D. (2017). Pengaruh Likuiditas dan Struktur Modal Terhadap Nilai Perusahaan dengan Profitabilitas sebagai Variabel Intervening pada Perusahaan yang Terdaftar di Bursa Efek Indonesia. EQUITY. Vol. 20 Issue 1. ISSN (Print): 0216-8545 ISSN (Online): 2684-9739.

[16] Hermawan, S., Hanum, N. R., \& Pamungkas, N. (2019). Intellectual Capital, Financial Performance and Market Performance: Evidence From High IC Intensive Company in Indonesia. Jurnal Dinamika Akuntansi. Vol. 11, Issue 2, September 2019, pp. 98-107.p-ISSN \begin{tabular}{l|ll}
$2085-4277$ & e-ISSN & 2502-6224
\end{tabular} http://journal.unnes.ac.id/nju/index.php/jda.

[17] Horne, J. C. V \& Wachowicz, J. M. (2009). Fundamental of Financial Management: Prinsip-Prinsip Manajemen Keuangan. edition 12. Jakarta: Salemba Empat.

[18] Juanda, R. E., Fitriah, E., \& Rosdiana, Y. (2016). Pengaruh Intellectual Capital terhadap Profitabilitas (ROA) (Studi pada Perusahaan Sektor Manufaktur Subsektor Logam dan Sejenisnya). Prosiding Akuntansi. Volume 2, Issue 1. ISSN: 2460-6561.

[19] Jayanti, L. D., \& Binastuti, S. (2017). Pengaruh Intellectual Capital terhadap Nilai Perusahaan dengan Kinerja Keuangan sebagai Variabel Intervening pada Perusahaan Perbankan yang Terdaftar di Bursa Efek Indonesia. Jurnal Ekonomi Bisnis. Vol 22 Issue 3 pp 187-198.

[20] Jensen, M. C., \& Meckling, W. H. (1976). Theory of The Firm Managerial Behaviour, Agency Costs, and Ownership Structure Journal of Financial Economics. Vol. 3 Issue 4, October, pp 305-360

[21] Kamath, G.B. (2007). The intellectual Capital Performance of Indian Banking sector. Journal of Intellectual Capital. 8(1),pp 96-123.

[22] Kazhimy, A. F., \& Sulasmiyati, S. (2019). Pengaruh Intellectual Capital terhadap Profitabilitas Perusahaan (Studi pada Sektor Propert dan Real Estate Yang terdaftar di Bursa Efek Indonesia Periode 2015-2017). Jurnal Administrasi Bisnis (JAB). Vol. 72 Issue 2 July 2019. administrasibisnis.studentjournal.ub.ac.id.

[23] Kuspinta, T. D., \& Husaini, A. (2018). Pengaruh Intellectual Capital Terhadap Profitabilitas Perusahaan (Studi pada Perusahaan Manufaktur yang Terdaftar di Bursa Efek Indonesia Periode Tahun 2014-2016). Jurnal Administrasi Bisnis (JAB) Vol. 56 Issue 1 March 2018 administrasibisnis.studentjournal.ub.ac.id.

[24] Laksono, E. D. P., \& Pangestuti, I. R. D. (2018). Hutang dan Profitabilitas Perusahaan (Studi pada Perusahaan Real Estate dan Property Yang Listing di Bursa Efek Indonesia). Diponegoro Journal Of Management. Volume 7, Issue 4, pp $1-7$ http://ejournal-s1.undip.ac.id/index.php/dbr. ISSN $\quad$ (Online): 2337-3792.

[25] Lang, L., Stulz, R.M. \& Walkling, R.W. (1989). Managerial Performance, Tobin's 4 and the Gains from Successful Takeovers. Journal of Finance . 44, pp 771-789.

[26] Lestari. (2017). Pengaruh Intellectual Capital dan Kepemilikan Institusional terhadap Nilai Perusahaan. Jurnal Dinamika ekonomi \& Bisnis. Vol 14, Issue 1 march 2017.

[27] Li, Y., \& Zhao, Z. (2017). The Dynamic Impact of Intellectual Capital on Firm Value: Evidence From China. Applied Economics Letters. ISSN: 1350-4851 (Print) 1466-4291 (Online) Journal homepage: http://www.tandfonline.com/loi/rael20DOI:10.1080/13504851.2017.1 290769. http://dx.doi.org/10.1080/13504851.2017.1290769 .

[28] Mahardhika, P.A., \& Marbun, D.P. (2016). Pengaruh Current Ratio dan Debt To Equity Ratio terhadap Return On Assets. Widyakala. Vol.3 Maret 2016 pp 23 - 28. ISSN : 2337-7313.

[29] Maulana, M. R., Hermanto, \& Nugraha, I. N. (2016). Pengaruh keputusan Investasi, Keputusan Pendanaan dan Kebijakan Dividen Terhadap Nilai Perusahaan Pada Perusahaan LQ-45 di Bursa Efek Indonesia Tahun 2011-2015. Jurnal Distribusi. Jurnal Ilmu Manajemen dan Bisnis. Vol. 4, Issue 2 - September 2016 pp 29-50. p-ISSN: 0853-9571, e-ISSN: 2477-1767.

[30] Mariani, D, \& Suryani. (2018). Pengaruh Enterprise Risk Management Disclocure, Intellectual Capital Disclosure dan Corporate Social Responsibility Disclosure terhadap Nilai Perusahaan dengan Profitabilitas sebagai Variabel Pemoderasi (Studi Empiris Pada Perusahaan Sektor Industri Barang Konsimsi di Bursa Efek Indonesia Tahun 2012-2016). Jurnal Akuntansi dan Keuangan..Vol. 7 Issue 2, October 2018 ISSN: 22527141

[31] Mavridis, D.G. (2004). The Intellectual Capital Performance of the Japanese Banking Sector. Journal of Intellectual Capital 5 (3): 92-115.

[32] Modigliani, F., \& Miller, M. H. (1963). Corporate Income Taxes and the Cost of Capital: A Correction. The American Economic Review.
Vol. 53, Issue 3 (Jun., 1963), pp. 433-443. American Economic Association. URL: http://www.jstor.org/stable/1809167.

[33] Muna, N., \& Prastiwi, A. (2014). Pengaruh Intellectual Capital terhadap Return Saham Melalui Kinerja Keuangan pada Perusahaan Real Estate dan Properti yang Terdaftar di Bursa Efek Indonesia (BEI) Tahun 2010-2012. Diponegoro Journal of Accounting. Volume 3, Issue 2, pp 1-15.

[34] Myers, S. C \& Majluf, N.S. (1984). Corporate Financing \& Invesment Decision When Firm Have Information That Investor Do Not Have. Journal of Financial Economics. 13, pp 187-221.

[35] Myers, S. C. (2001). Capital Structure. The Journal of Economic Perspectives. 15(2), pp 81-102.

[36] Nimtrakoon, S. (2015).The Relationship Between Intellectual Capital, Frms' Market Value and Fnancial Performance: Empirical evidence from the ASEAN. Journal of Intellectual Capital. Vol.16 Issue 3, pp.587-618.

[37] Nurhayati, M. (2013). Profitabilitas, Likuiditas, dan Ukuran Perusahaan Pengaruhnya terhadap Kebijakan Dividen dan Nilai Perusahaan Sektor Jasa. Jurnal Keuangan dan Bisnis. 5(2): pp 144-153.

[38] Nuryaman. (2015). The Influence of Intellectual Capital on The Firm's Value with The Financial Performance as Intervening Variable. 2nd Global Conference on Business and Social Science-2015, GCBSS-2015, 17-18 September 2015, Bali, Indonesia. Procedia Social and Behavioral Sciences 211 ( 2015 ) pp $292-298$.

[39] Permatasari, D., \& Azizah, D. F. (2018). Pengaruh Struktur Modal terhadap Nilai Perusahaan. (Studi pada Perusahaan Sub Sektor Makanan dan Minuman Yang Terdaftar Di Bursa Efek Indonesia Tahun 2013-2016). Jurnal Administrasi Bisnis (JAB). Vol. 61 Issue 4 August 2018. administrasibisnis.studentjournal.ub.ac.id.

[40] Permatasari, D., Tulung, J. E., \& Tasik, H. H. D. (2018). Pengaruh Struktur Modal terhadap Kinerja Keuangan pada Perbankan Yang Terdaftar di Bursa Efek Indonesia Periode 2012-2016. Jurnal EMBA. Vol.6 Issue 2 April 2018, pp 610 - 619. ISSN 2303-1174.

[41] Petty, R. \& J. Guthrie. (2000). Intellectual Capital Literature Review: Measurement, Reporting and Management. Journal of Intellectual Capital. Vol. 1 Issue 2/3, pp. 155-76.

[42] Pratama, I. G. B., \& Wiksuana, I. G. B. (2018). Pengaruh Ukuran Perusahaan dan Leverage terhadap Nilai Perusahaan dengan Profitabilitas sebagai Variabel Mediasi. E-Jurnal Manajemen Unud. Vol. 5, Issue 2, 2016: 1338-1367 ISSN : 2302-8912.

[43] Prakoso, P. G. R \& Chabachib, M. (2016). Analisis Pengaruh Current Ratio, Size, Debt to Equity Ratio, dan Total Asset Turnover Terhadap Dividend Yield dengan Return on Asset sebagai Variabel Intervening. Diponegoro Journal of Marketing. Volume 5, Issue 2, pp 1-14 http://ejournal-s1.undip.ac.id/index.php/dbr. ISSN (Online): 2337-3814.

[44] Prihadi, T. (2013). Analisis Laporan Keuangan Lanjutan: Proyeksi \& Valuasi. Cetakan 1. Jakarta Pusat: PPM Manajemen.

[45] Pulic, A. (1998). Measuring the Performance of Intellectual Potential in Knowledge Economy. Paper presented at the 2nd McMaster Word Congress on Measuring and Managing Intellectual Capital by the Austrian Team for Intellectual Potential.

[46] Putri, S. D., \& Nuzula, N. F. (2019). Pengaruh Intellectual Capital terhadap Kinerja Keuangan dan Nilai Perusahaan (Studi pada Perusahaan Sektor Manufaktur yang Terdaftar di Bursa Efek Indonesia Periode 2012-2017). Jurnal Administrasi Bisnis (JAB). Vol 66 Issue 1 Januari 2019. Administrasibisnis.studentjournal.ub.ac.id.

[47] Rahmantio, I., Saifi, M., \& Nurlaily, F. (2018). Pengaruh Debt To Equity Ratio, Return On Equity, Return On Asset dan Ukuran Perusahaan terhadap Nilai Perusahaan (Studi pada Perusahaan Pertambangan yang Terdaftar di Bursa Efek Indonesia tahun 2012-2016). Jurnal Administrasi Bisnis (JAB), Vol. 57 Issue 1 April 2018. administrasibisnis.studentjournal.ub.ac.id. pp 151-159.

[48] Ramadita, E. S \& Suzan, L. (2019). Pengaruh Biaya Produksi, Debt to Equity Ratio dan Perputaran Persediaan Terhadap profitabilitas Jurnal ASET (Akuntansi Riset). Vol 11. Issue 1, 2019, pp 159-168.

[49] Roos, J., Edvinsson, L. \& Dragonetti, N.C. (1997). Intellectual Capital: Navigating the New Business Landscape. Springer. NewYork, NY.

[50] Sabrin, B. S., Takdir, D \& Sujono. (2016). The Effect of Probability on Firm Value in Manufacturing Company at Indonesia Stock Exchange. The International Journal of Engineering And Science (IJES) Volume 5 Issue 10 pp 81-89. ISSN (e): 2319 - 1813 ISSN (p): 2319 1805 .

[51] Sardo, F., Serrasqueiro, Z., \& Alves, H. (2018). On the Relationship Between Intellectual Capital and Financial Performance: A Panel Data Analysis on SME Hotels, International Journal of Hospitality Management, 75, September: pp 67-74. IF: 3,445. https://doi.org/10.1016/j.ijhm.2018.03.001b 
The Effect of Funding Decisions and Intellectual Capital on Firm Value with Profitability as an Intervening Variable in Manufacturing Companies Listed on the Indonesia Sharia Stock Index

[52] Sari, N. (2017). Pengaruh Struktur Modal dan kebijakan Hutang terhadap Nilai Perusahaan pada Perusahaan Manufaktur Sektor Tekstil dan Garmen Periode 2010-2014 di Bursa Efek Indonesia. JOM Fisip. Vol. 4 Oktober 2017.

[53] Sartono, A. (2010). Manajemen Keuangan Teori dan Aplikasi. Edisi Keempat. Yogyakarta: BPFE.

[54] Scott, J. H. Jr. (1977). Bankruptcy, Secured Debt, And Optimal Capital Structure. The Journal of Finance. Vol XXXII, No 1, March 1977. https://doi.org/10.1111/j.1540-6261.1977.tb03237.x.

[55] Simanungkalit, P. 2015. Pengaruh Intellectual Capital terhadap Nilai Perusahaan dengan Kinerja Keuangan sebagai Variabel Intervening (Studi pada Perusahaan Manufaktur yang Terdaftar di BEI Periode 2009-2013. Diponegoro Journal of Management. Volume 4, Issue 3, Halaman 4. http://ejournal-s1.undip.ac.id/index.php/dbr.

[56] Sudaryo, Y., \& Pratiwi, I. Y. (2016). Pengaruh Struktur Modal dan Likuiditas Terhadap Profitabilitas dan Dampaknya terhadap Kinerja Keuangan. Jurnal Indonesia Membangun. ISSN 1412-6907. http://jurnal-inaba.hol.es. Vol. 15, Issue 2. Mei-August 2016.

[57] Sudibya, D. C. N. A \& Restuti, M. M. D. (2014). Pengaruh Modal Intelektual terhadap Nilai Perusahaan dengan Kinerja Keuangan sebagai Variabel Intervening. BENEFIT Jurnal Manajemen dan Bisnis. Volume 18, Issue 1, Juny 2014, pp $14-29$.

[58] Smriti, N., \& Niladri, D. (2018). The Impact of Intellectual Capital on Firm Performance: a Study of Indian Firms listed in COSPI. Journal of Intellectual Capital. Vol. 19 Issue: 5, pp.935-964, https:// doi.org/10.1108/JIC-11-2017-0156.

[59] Tanudja, M. A., \& Hastuti, R. T. (2019). Pengaruh Aktivitas Rasio Keuangan terhadap Nilai Perusahaan Manufaktur yang Terdaftar di BEI. Jurnal Multiparadigma Akuntansi. Volume I Issue. 3/2019 pp 683-692.

[60] Tauke, P. Y., Murni, S., \& Tulung, J. E. (2017). Pengaruh Kinerja Keuangan terhadap Nilai Perusahaan Real Estate dan Property yang Terdaftar di Bursa Efek Indonesia tahun 2012-2015. Jurnal EMBA Vol.5 Issue 2 Juny 2017, pp $919-927$.

[61] Tobin's, J. (1969). A General Equilibrium Approach to Monetary Theory. Journal of Money, Credit and Banking (February). 1229.

[62] Ulum, I. (2008). Intellectual Capital Performance Sektor Perbankan di Indonesia. Jurnal Akuntansi Keuangan. Vol. 10, Issue 2, November 2008: pp 77-84.

[63] Ulum, I. (2017). Intellectual Capital: Model Pengukuran, Framework Pengungkapan \& Kinerja Organisasi. Cetakan ketiga. Malang: UMM Press.

[64] Utami, E. M. (2019). The Intellectual Capital Components on Firm Value: Evidence from LQ-45 Index Companies. Jurnal Keuangan dan Perbankan, 22(2): pp 291-300, 2018. ISSN: 2443-2687 (Online)nISSN: 1410-8089 (Print). http://jurnal.unmer.ac.id/index.php/jkdp.

[65] Widiyanti, M., \& Elfina, F. D. (2015). Pengaruh Financial Leverage Terhadap Profitabilitas Pada Perusahaan Sub Sektor Otomotif dan Komponen Yang Terdaftar di Bursa Efek Indonesia. Jurnal Manajemen dan Bisnis Sriwijaya. Vol.13 Issue 1 March 2015. Pp 117-136.

[66] Whiting, R. \& Miller, J. (2008). Voluntary Disclosure of Intellectual Capital in New Zealand Annual Reports and the Hidden Value. Journal of Human Resource Costing \& Accounting. Vol. 12 Issue 1, pp. 26-50. https://doi.org/10.1108/14013380810872725.

[67] Yulandari, L. F \& Gunawan, H. (2019). Pengaruh Intellectual Capital terhadap Nilai Pasar dan Kinerja Keuangan Perusahaan yang Terdaftar di Bursa Efek Indonesia. Journal Of Applied Managerial Accounting. Vol. 3, Issue 1, March 2019, pp 36-50ISSN: 2548-9917 (online version).

[68] Yuskar \& Novita, D. (2014). Analisis Pengaruh Intellectual Capital terhadap Nilai Perusahaan dengan Kinerja Keuangan Sebagai Variabel Intervening Pada Perusahaan Perbankan di Indonesia. Jurnal Manajemen dan Bisnis Sriwijaya. Vol.12 Issue 4 Desember 2014.

[69] DetikFinance. Sektor Manufaktur Masih Jadi Andalan Genjot Pertumbuhan Ekonomi RI. Access at Wednesday, March 21, 2018 20:03 WIB. Writer: Hendra Kusuma. https://finance.detik.com/industri/d-3929902/sektor-manufaktur-masi h-jadi-andalan-genjot-pertumbuhan-ekonomi-ri.

[70] Kontan.co.id. (2019). Dirut BEI: Jumlah Investor Syariah Tumbuh Pesat, Pasar Modal Syariah Kian Potensial. Thuesday, 08 August 2019. Reporter: Akhmad Suryahadi, Editor: Komarul Hidayat. https://investasi.kontan.co.id/news/dirut-bei-jumlah-investor-syariah-t umbuh-pesat-pasar-modal-syariah-kian-potensial.

[71] www.idx.co.id. Produk Syariah. Website https://www.idx.co.id/idx-syariah/produk-syariah/. 